\title{
Elevers minnen från slöjdundervisning
}

\author{
Annelie Holmberg
}

Syfte är att $i$ essäform föra ett resonemang om egentillverkade föremåls position $i$ minnen från slöjdundervisning. Varför minns vi föremål och vad kan bidra till minnens tillsynes starka position? Empirin består av skriftliga minnena, i form av ett urval om drygt 200 brev från elever som deltagit $i$ slöjdundervisning. Breven är resultatet av ett publikt upprop inför utställningen Skolslöjd vid Nordiska museet år 2012. Analysen är genomförd genom en kvalitativ textanalys av brevens innehåll. Som stöd $i$ resonemanget kring resultatet av brevens analys används begrepp och tankegångar från litteratur och forskning med fokus på minnen av föremål och ett meningsskapande $i$ samband med tillverkning av föremål. Utöver detta används även forskning om minnen från undervisning. Texten, analys och litteratur $i$ samverkan, visar avslutningsvis att föremål kan hjälpa individen att minnas men att dessas betydelse påverkas av bland annat tid och kontext. Föremålen både formar och framkallar minnen. Elevens upplevelser (såväl positiva som negativa) av föremålet och tillverkningen av dessa tycks påverka de minnen som skapas. Empirin och den valda litteraturen bidrar tillsammans till förståelse om vad elever minns och detta bidrar till reflektion gällande föremålens roll $i$ slöjdundervisning och undervisningens utformning.

Grytlappen som blev en fot... Ja det var ju meningen att bli en grytlapp! Men det var inte så lätt att hålla spänsten på virkningen i början... så när det började barka åt $h .$. så tänkte jag om och beslutade mig för att det var en fot som var målet. Bara att börja virka tår!

Citatet som får inleda denna essä är från ett brev som förmedlar minnen från slöjdundervisning under 1970-talet. Den tidigare eleven förmedlar färgstarkt sin upplevelse av en undervisningssituation långt tillbaka i tiden. Eleven minns sin grytlapp som blev en fot, men även känslan av att något inte blev som planerat och att detta nog berodde på oförmåga att hålla garnet på det sätt som gav det bästa eller önskade resultatet. Vad gör att eleven minns detta så väl och minns hen undervisningen i fysik eller geografi lika detaljerat? Minnen från skolan benämns internationellt school memories och syftar enligt Meda och Viño (2017, s. 2) på minnen som på olika sätt knyter an till skola och undervisning och vad som brukar refereras till som den egna skoltiden och sammantaget utgör minnen som "individer, olika gemenskaper och samhället byggt upp om 
skolvärlden och utbildningsprocessen" (förf. översättning). Minnen från tiden i skolan påverkas av den tid då de skapades, samtidigt påverkas de av tiden som förflutit sedan dessa skapades. Detta innebär att det förflutna inte är bevarat utan är en rekonstruktion baserad på en nutid (Halbwachs, 1992). Minnen är inte precisa och konstanta utan föränderliga; de kan därför förändras många gånger utifrån när de återuppstår.

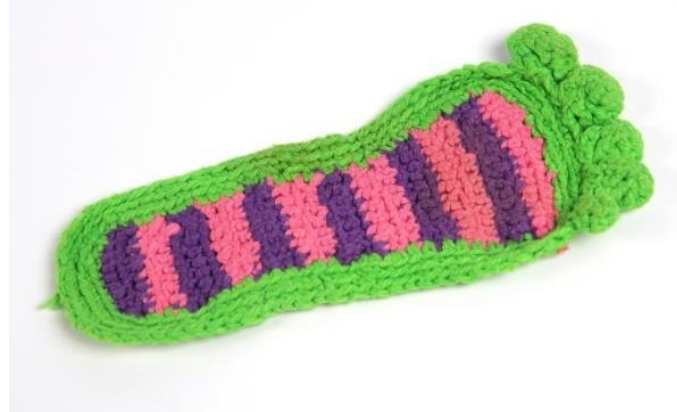

Bild 1. Grytlappen som blev en fot är ett av de föremål som donerades till Nordiska museet i samband med utställningen om skolslöjd. (SKOLSLÖJD/2011)

Känslor i samband med en upplevelse påverkar enligt Halbwachs (1992) skapandet av minnen. Något som upplevs som svårt eller kränkande skapar starka minnen hos individen. Att dessa upplevelser kan vara ett resultat av undervisning framgår av argumentation förd av Dewey (1938/1997). Dewey argumenterar för att erfarenhetsbaserat lärande är ett lärande som skall leda till individens utveckling. I detta lärande är meningsfullhet viktigt, en meningsfullhet som då det gäller slöjd skulle kunna knytas till undervisningens mål, och i förlängningen vilka föremål som tillverkas samt varför dessa valts. Dewey skiljer mellan erfarenheter som är "educative and those that mis-educated" (1938/1997, s. 27) och anser att det sistnämnda (oönskat lärande) kan leda till ett lärande som hämmar en fortsatt utveckling.

Området school memories med anknytning till slöjd är mindre beforskat och det finns få studier med minnen som ingång. Målsättning med denna essä är därför att med nedskrivna brev som källa föra ett resonemang kring om det kan finnas en grund till att minnen från slöjdundervisning, som formats och omformats över tid, fortsatt består. Att resonera kring dessa hågkomster från slöjdundervisning kan bidra med kunskap om skolans "inre liv" (Ascenzi \& Patrizi, 2016) och därmed fylla kunskapsluckor om en kroppsligt erhållen kunskap vilken materialiserats då ett föremål tillverkats. 
Syfte med essän är att föra ett resonemang om egentillverkade föremåls position i minnen från slöjdundervisning. Vad berättar eleverna att de kommer ihåg och hur kan detta bidra till att förklara vissa minnens tillsynes starka position? Hur påverkas ett minne av att föremålet även är tillverkat av den som minns? Vad berättar litteratur och tidigare forskning om förekomsten av föremål och tillverkningen av föremåls påverkan på individers minnen? Min essä har ett tydligt fokus på slöjd. Jag anser dock att syftet har implikationer på en vidare sfär genom att resonemanget skulle kunna appliceras på lärande i stort. Ordet resonera är viktigt här. Inga konkreta svar kommer att ges, snarare kommer tankegångar kring brevens innehåll relaterade till litteratur som på olika vis berör ämnet att presenteras.

Inledningsvis presenteras nedan det brevmaterial som bildar empiri. Insamling, urval och analysmetod redovisas. I ett eget avsnitt ges sedan exempel på hur föremål och tillverkningen av föremål skrivs fram i breven. Därefter följer essäns huvuddel som innefattar ett resonemang om minnen från slöjdundervisning relaterade till litteratur. Avslutningsvis diskuteras eventuella implikationer och möjligheter som essän kan peka mot.

\section{Minnen förmedlade i brev}

Som empiri används brev vilka samlats in av Nordiska museet 2011 (Skolslöjd/2011). Breven är svar på det upprop som museet publicerade inför utställningen Skolslöjd som hade vernissage 2012. Syftet med uppropet var att erhålla berättelser och slöjdföremål från elever. Genom uppropet fick museet del av elevers minnen från undervisning $i$ slöjd och utställningen kunde presentera även ett elevperspektiv på slöjd. Uppropet löd:

Vad gjorde du i slöjden? Berätta ditt slöjdminne! Alla som har en grytlapp eller smörkniv från skolslöjden får gärna skicka in den till Nordiska museets utställning! Museet vill även ha berättelser om det som blev fel eller fult, det man avskydde att göra eller det som var roligt och som man blev nöjd med i sy- och träslöjden. Den som har andra slöjdalster kvar, såväl avslutade som oavslutade och misslyckade, är välkommen att skicka in en bild eller beskriva dem i texten. Då kan de eventuellt också visas i utställningen. (SKOLSLÖJD/2011)

De skriftliga hågkomsterna, i form av ett urval om drygt 200 av de totalt 500 breven, skiljer sig från övriga slöjdminnen som tas upp i denna essä genom att de är inskickade på initiativ av brevskrivaren, utan uppmuntran från en forskare. De 200 breven valdes utifrån kriterierna att brevskrivaren förmedlar sina egna minnen och att tidsangivelse för den undervisning som beskrivs finns med. Breven bidrar med en skildring av slöjdundervisning från 1930-tal fram till och med 2011 och materialets skriftliga form understödde bruket av en kvalitativ 
textanalys av innehållet. Den kvalitativa textanalysen är en del av den hermeneutiska traditionen, vilket innebär att texter tolkas genom att de läses med målsättningen att skapa mening (Widén, 2009; Bergström \& Boréus, 2000). I denna analys har vad som är centralt - det vill säga vad brevskrivaren valt att ta upp i sitt brev - identifierats. Olika teman har därefter identifierats utifrån en systematisering av innehållet. I systematiseringen finns kvantitativa inslag genom att vilket innehåll som dominerar noterats. Exempel på detta är att de föremål som tillverkats i undervisningen - produkter - är det som brevskrivarna valt att skildra flest gånger. De teman som identifierats är: produkt, känslor, lärare, undervisning, görande/slöjdande och vad slöjden gav.

Breven har skrivits och skickats med en utgångspunkt i informantens egen vilja att delge något de kommer ihåg. Detta visar att brevskrivaren har en önskan om att delge något, samt att hågkomsterna från slöjdundervisning troligen var starka då ett allmänt upprop hörsammats. Breven utgör ett anonymiserat material. Det finns i några av breven i arkivet exempelvis adressuppgifter till några av brevskrivarna. I min analys har detta tagits bort och materialet har anonymiserats.

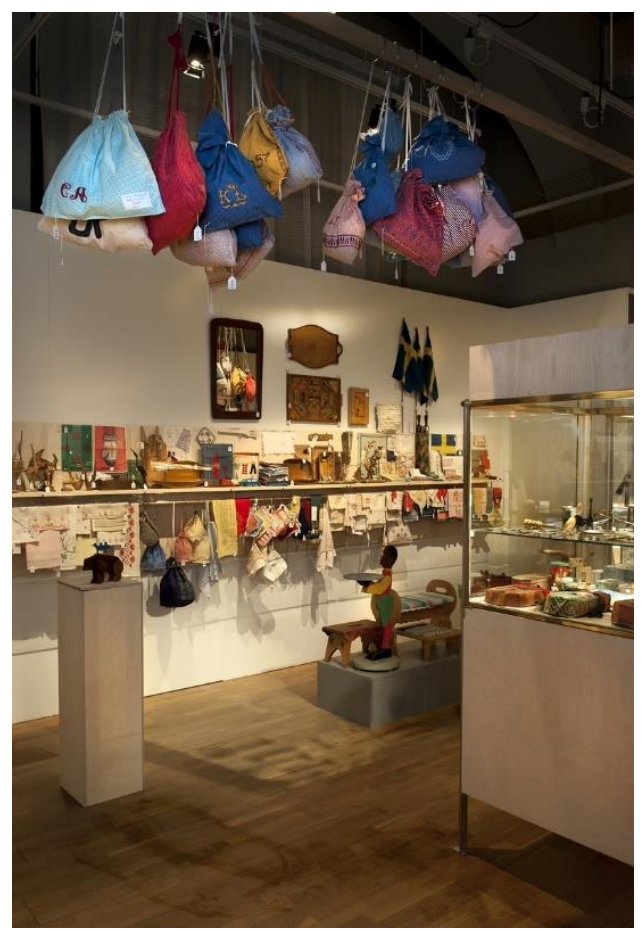

Bild 2. Utställningsrummet på Nordiska museet år 2012 var fyllt av föremål tillverkade av elever. Slöjdpåsar, pallar och flaggor förmedlade en berättelse om svensk slöjdundervisning över tid. 
Breven är till övervägande del skrivna av kvinnor och minnen från slöjd i de textila materialen dominerar. Trots detta har jag valt att behandla slöjd som ett ämne, inte utifrån de två materialinriktningarna trä och metall eller textil som undervisningen delades upp i under den period som breven skildrar. Om det är minnet av själva föremålet eller tillverkningen i det ena eller andra materialet har bortsetts från - elevernas minnen av föremålen och upplevelsen av att tillverka dem har varit det intressanta oavsett materialinriktning.

\section{Vad minns elever - hur minns elever}

För att exemplifiera hur föremål och den egna tillverkningen av föremålen skrivs fram i breven ges nedan några exempel utifrån de olika teman, som nämns ovan. Teman har identifierats genom en innehållsanalys av breven. I presentationen nedan har inte tiden då brevet skrivits ansetts viktig, utan breven behandlas här som en enhet av minnen.

I de minnen som förmedlas i breven har produkterna, det vill säga slöjdföremålen som tillverkats, en central roll. Ett specifikt föremål kan vara i fokus eller så är föremålet en del i ett minne om exempelvis lärare eller undervisning. Föremål ingår därmed i flera av kategorierna men kan även bilda en egen kategori. Detta kan ha påverkats av uppropets formulering om "vad" tidigare elever gjort i slöjden eller det faktum att grytlappar och smörknivar nämns. Citatet nedan är ett exempel på hur minnen av slöjdundervisning förmedlas med hjälp av föremål:

Första uppgiften var att sticka en grytlapp. Den blev hård, liten och helt oanvändbar. Sedan sydde vi en slöjdpåse. Följande läsår skulle vi sticka ett par raggsockor. Ett helt år kämpade jag med dem. Att min mamma skulle hjälpa mig var helt otänkbart. Hon var folkskollärarinna och kollega till slöjdfröken.

Den tidigare eleven minns grytlappen, slöjdpåsen och raggsockorna, hur föremålen kändes att hålla i och vilken ensam kamp det var att tillverka dem. Minnet är från 1940-talets undervisning. Den tidigare eleven minns därmed en oanvändbar produkt som tillverkades cirka 70 år innan brevet skrevs. En annan aspekt som tas upp rör att föremålen som tillverkades ofta sparats, oavsett om de var funktionella eller inte. Här ett minne från 1970-talets slöjdundervisning:

Det hamnade i uthuset på landet och varje gång jag ser fatet ligga där, vänder jag mig bort. Åsynen av det väcker tråkiga minnen. Ändå har det undsluppit vedkaminen, mycket beroende på allt jobb jag lagt ner på träfatet.

Även minnen av undervisningen och arbetsprocessen i slöjd är centrala delar i de skriftliga berättelserna. I dessa minnen beskrivs lärarens roll, bristen på eller möjligheten till elevinflytande samt strukturella förändringar som påverkat 
undervisningen. Upplevelserna är i många fall beskrivna i mycket positiva alternativt negativa ordalag. Lärares kränkningar eller det hårda arbetet med material och uppgifter som uppfattades som svåra beskrivs med stor inlevelse. Slöjdandet, den erfarenhetsbaserade kunskapen, minns eleverna genom de omständigheter som omger och formar det. I citatet som följer beskriver en elev 1980-talets slöjd med en undervisning som upplevdes kreativ och som skiljde sig från övrig undervisning i skolan:

Lektionerna var långa och man hade tid "to get into it". Det var inget tjafs. Jag tror mig komma ihåg att lektionerna var väldigt fria, det var kreativt och därigenom ett trevligt avbrott från dom andra lektionerna - " the intellectual slog, haha". Jag tyckte om själva arbetsgången och materialet men var tyvärr aldrig särskilt nöjd med resultatet.

\section{Slöjdande och föremål - dess plats i minnen från undervisning}

Jag har valt att skriva denna essä för att få möjlighet att föra ett resonemang kring egentillverkade föremåls position i minnen från slöjdundervisning och huruvida detta minne påverkas av att eleven själv tillverkat föremålet $i$ en slöjdprocess. Litteratur från olika forskningsområden vilka jag bedömt som relevanta kommer att relateras till resultatet av en analys av brevens innehåll. Texten nedan är strukturerad under rubrikerna föremål och görande/slöjdande. I text under rubrikerna inkluderas lärarens roll, detta då läraren samt exempelvis rådande kursplan eller material för slöjdande enligt analysen tycks inverka på minnen av undervisning i slöjd.

\section{Föremåls position i minnet}

I denna essä är minnen från slöjdundervisning i fokus. Med målsättning om ett vidgat perspektiv och att få till stånd en förankring av mitt resonemang i fler forskningsfält än slöjdens, förs inledningsvis ett resonemang om föremåls position för individer ur ett mer allmänt perspektiv.

Föremål är en del av det som definieras som "materiell kultur" och, enligt Glassie (1999), innefattar den vidare definitionen av detta allt som är ickelevande och som oftast är tillverkat av människor. I publikationen Material cultures; Why things matter (Miller, 1998) ges flera exempel på hur föremål kan spela en central roll för att belysa en rad olika frågeställningar, att föremål spelar en viktig roll anses redan vara befäst genom tidigare forskning. Undertiteln "Why things matter", skrivet utan frågetecken, är ett tydligt ställningstagande om att föremål är av betydelse. Centralt är att ha kriterier för varför något är av betydelse och att kriterierna måste utgå från material och den kontext som berörs (Miller, 1998). De brev som är källmaterialet i denna essä tillhör en tydlig kontext, minnen från svensk slöjdundervisning. Ett kriterium för huruvida den materiella kulturen, i form av föremål, är av betydelse för brevskrivarna kan 
vara att föremålen förekommer med hög frekvens i breven. Även det faktum att föremålen är det centrala i de flesta berättelser, att hågkomster med andra aspekter i fokus förmedlas via föremålen, kan tyda på att föremål har betydelse.

Föremålens betydelse kan variera från individ till individ och måste knytas till kontext och/eller tid som förflutit sedan en upplevelse och upplevelsens karaktär. I Wettsteins (2009) avhandling Livet genom tingen skildras föremåls betydelse för människor som upplevt traumatiska händelser. Ämnet i denna avhandling skiljer sig naturligtvis från minnen som skapats vid slöjdundervisning, trots detta finns i Wettsteins analys aspekter som är relevanta här. En aspekt som lyfts är att "[T]tingens förmåga att återskapa händelser i det förflutna är i första hand beroende av innehavaren, hur de läser föremålen" (2009, s. 130). Föremålen kan ha en fast betydelse men betydelsen kan även påverkas av en tolkning genom ett erfarenhetsraster. Ett föremål kan därmed ha flera betydelser för en individ. Utöver detta kan föremål även fungera som en påminnelse av något som skett och att föremålen hjälper oss att minnas oavsett hur lång tid som förflutit (Gunnemark, 2004). Föremålen hjälper således individen att minnas och reflektera.

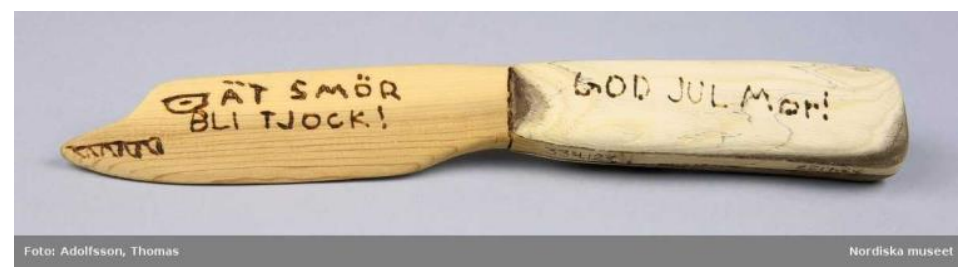

Bild 3. Elev under1990-talet minns: "Jag [...] gillade Rambo, därav formen på kniven. Jag tror även att utsmyckningen på nosen inspirerats av stridsflygplan från USA, efter 2:a världskrigets slut. Jag kan inte i dagsläget förstå varför jag gav den till mamma och vad texten skulle syfta till.”

Brevskrivarnas hågkomster av föremål har alltså en betydelse för att återskapa minnen men de är även en tolkning utifrån en referensram individen erhållit sedan den faktiska upplevelsen. Ett exempel på detta skulle kunna vara de bebiskläder som tillverkades i skolslöjden. Enligt en brevskrivare kunde det på 1940-talet gå till på följande vis:

I slöjden förbereddes vi genom att sticka/virka/sy en babyutrustning bestående av mössa, kofta, sparkbyxor, örngott bl.a. Detta lades i en låda som vi klätt med babymönstrat tyg. Pricken över i:et var att få välja att sy en brudslöja eller dopklänning. 
Kanske upplevde tonåringen inte dessa produkter som problematiska, men ett vuxenperspektiv med en erfarenhet om att inte alla väljer eller kan skaffa barn leder till en vidgad tolkning av föremålen. En persons erfarenhetsraster kan då bidra till att ett föremål får en framträdande position, att föremålet har betydelse, i ett minne från slöjdundervisning.

Rasmussen (2012) har i intervjuer med tidigare elever i den danska grundskolan, kommit fram till att föremål spelar en viktig roll då det gäller att minnas sin skoltid. Här är det inte specifikt slöjd som skildras utan undervisning generellt.

The way materiality (memory objects) crops up in the memories of former pupils illustrates the way in which the past is forced up on us, entering the present via memory objects (Rasmussen, 2012, s. 127).

Föremålens existens påminner om en tid som varit; de är en ständig påminnelse om dåtiden samtidigt som de interagerar med en samtid. De fungerar både bevarande och återskapande av minnen. Skillnaden mellan de ölbackar, reservoarpennor och klassdjur Rasmussens informanter minns och de slöjdföremål som brevskrivarna kommer ihåg är dels att de sistnämnda tillverkat föremålen själva men även att dessa ofta finns kvar i förråd eller hem. De sistnämnda informanterna har ofta aktivt valt att spara det föremål som kan bidra till att skapa och återskapa ett minne.

Föremål i minnen från slöjdundervisning skildras av såväl Marjanen, Lindfors och Ketola (2018) och Borg (2001). Föremålens centrala roll i hågkomster från slöjdundervisning syns tydligt i resultatet av den finska intervjustudien som behandlar tre generationers minnen från slöjdundervisning (Marjanen, Lindfors \& Ketola, 2018). Fyra av sju kategorier i det sammanställda resultatet visar att informanternas minnen har anknytning till föremålet, ytterligare en kategori tar upp föremålet genom elevens (eventuellt varierande) valfrihet i designprocessen. Vikten av föremålets användbarhet samt huruvida eleven var nöjd eller inte nöjd med det som tillverkats är en central del i resultat, vilket överensstämmer väl med resultatet av analysen av breven i Nordiska museets arkiv. Informanterna i båda studierna berättar detaljerat om slöjdprodukter och upplevelsen av dessa, exempelvis minnet av plagg som var för stora eller omoderna tycks ha en central position i skapandet av minnen. Ett exempel på detta är minnet av ett nattlinne som syddes under 1950-talet, som aldrig kom att vara lagom i storlek:

Mitt tydligaste minne är dock från femte eller sjätte klass då jag skulle sy ett nattlinne. Nattlinnet skulle vara väl tilltaget i storlek så att "jag hade något att växa i". För min del var nattlinnet så väl tilltaget att jag aldrig vuxit i det. 
Elever tycks tydligt komma ihåg föremål då de upplevt att mål inte uppnåtts eller då den egna föreställningen om ett resultat inte överensstämmer med det faktiska resultatet. Upplevelsen har skapat minnen som bevarats i årtionden och kanske är detta en av anledningarna till att föremål sparats, trots att de varit obrukbara. Att föremålet är viktigt i tidigare elevers hågkomster från slöjdundervisning kommer även Borg $(2001$, s. 84) fram till, "[K]kanske är det föremålet som är slöjdämnets speciella kännetecken". Detta skulle kunna vara en förklaring till föremålens starka position i tidigare elevers minnen. Föremålen som resultat av en tillverkningsprocess är det som består även om Borg (2001, s. 75) benämner dessa som "slöjdämnets ytliga representation". Nyttan med, eller föremålens användbarhet, tycks ur ett elevperspektiv vara en viktig del i detta minne.

\section{Görandets position i minnet}

I breven förmedlas en stor mängd minnen av slöjdande, det vill säga minnen av den handlingsburna kunskapen i slöjdundervisningen. Undervisningen i slöjd, och därmed lärandet av slöjd, har flera beståndsdelar och lärandet genom att tillverka föremål är bara en av dessa. Utifrån brevens innehåll har jag här valt att fokusera på denna del av undervisningen, då en övervägande del av de skildringar som innefattar minnen från undervisning berör just upplevelsen av att utföra ett hantverk.

Ett lärande av slöjd kan förknippas med hantverk då lärandet i slöjd sker genom handlingar. Enligt Sennett består en hantverkares arbete av:

a dialogue between concrete practices and thinking; this dialogue evolves into sustaining habits, and these habits establish a rhythm between problem solving and problem finding (2008, s. 9).

Elever utbildas inte till hantverkare genom att delta i slöjdundervisning, samtidigt finns i lärandet en grundtanke om den pendling mellan eller rytmen $\mathrm{i}$ problemlösning och upptäckten av problem som Sennett nämner. De minnen som förmedlas i breven till Nordiska museet beskriver dock främst upplevelsen av att ha fastnat i problem och väldigt sällan en upplevelse av att lösa problem. Rytmen uteblir och minnet av undervisningen i slöjd blir negativt. 


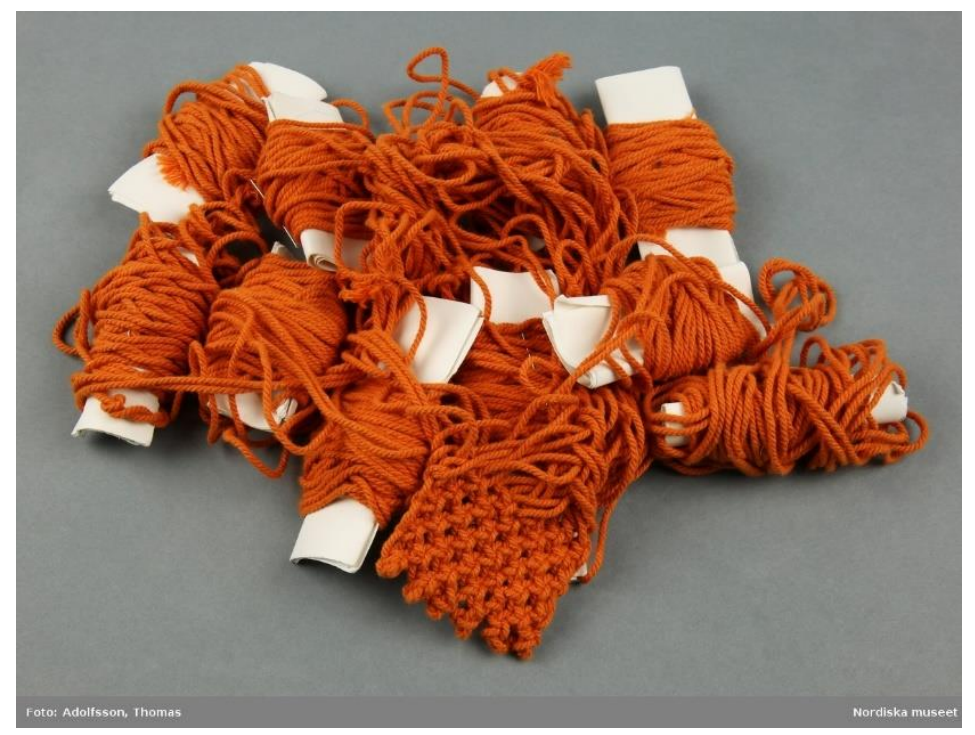

Bild 4. På bilden återfinns ett exempel på ett oavslutat elevprojekt, förklarat genom donators uttalande nedan.

Informanterna i studien av Marjanen, Lindfors och Ketola (2018) minns slöjden som tidskrävande, att tillverkningen tar lång tid. Även i breven i Nordiska museets arkiv finns berättelser om upplevelsen av tidskrävande processer, fållning med hålsöm eller stickning av vantar som aldrig tycktes bli klar. De flesta brevskrivarna var då de skrev breven vuxna och förmedlar minnet av en arbetsprocess som barnet/ungdomen upplevde som oändlig. I breven förmedlas inga minnen av att det gick fort att tillverka något, dock några minnen om glädjen av att tillåta en tillverkning att ta tid. Kanske är det barnets perspektiv på tid som återspeglas i såväl breven som i Marjanens m.fl. intervjuer - en inte helt ovanlig barnslig otålighet som inte alltid passade in i slöjdens arbetsmetoder. Här finns även kopplingar till utförandet av hantverk som en tidskrävande process och en förutsättning för ett gott resultat (Sennett, 2008). De föremål som eleverna tillverkade kan troligen inte alltid anses vara avancerade hantverksprodukter, trots detta är tillverkningen tidskrävande. Här påverkar exempelvis elevens förkunskaper, förväntningar på resultatet och inte minst lärarens pedagogik - allt detta formar elevens upplevelse och minne av arbetsprocessen. I citatet nedan beskrivs en sådan upplevelse:

Makramébanden vill jag minnas att vi gjorde i 6:an. Det var inget arbete som gav några bestående minnen, och jag kan inte komma ihåg att jag tyckte det 
var speciellt roligt eller tråkigt. Men som ofta hände (inte bara mig) så blev de inte färdiga under utsatt tid, utan fick förbli oavslutade, för att man skulle gå vidare med nästa moment. Bidragande till att en del saker inte blev färdiga, var att vi elever ofta behövde mycket hjälp, och att långa stunder gick åt till att vänta på hjälp från läraren.

Enligt Westerlund (2015) kan elevers upplevelse av lust eller olust vara beroende av om de aktiviteter eleven utför i slöjden upplevs som personligt meningsfulla eller inte. Olusten uppstår då eleven i sitt slöjdande möter motstånd som hindrar och begränsar det egna handlingsutrymmet. I breven finns flertalet hågkomster av att undervisningen i slöjden inte kändes meningsfull, av oanvändbara produkter och en kunskap som inte sågs som viktig för vuxenlivet. I flertalet fall framkommer att upplevelsen av lärares fokus på noggrannhet och att de egna misstagen blev tydliga i de färdiga föremålen, samt att detta ledde till långa arbetsprocesser, påverkar känslan av meningsfullhet. Samtidigt finns minnen av en annan upplevelse. En elev skriver om slöjdundervisning under 2000-talet att: "Jag lärde mig mycket under tiden då jag skapade mitt skåp. Framför allt att saker och ting inte är så svårt om man har en stark vilja och positivt tänkande". Här framkommer det tydligt att eleven sett processen som meningsfull och därmed lustfylld, kanske är det därför eleven minns denna positiva upplevelse. Kanske fick tillverkningen ta den tid som process och problemlösning krävde eller kanske var svårighetsnivån här rätt för eleven.

Att starka upplevelser i samband med undervisning skapar minnen framkommer i en dansk intervjustudie om skolminnen av Tanggard och Nielsen (2013). Studien visar att förklaringen till en hågkomst från slöjden inte enbart kan knytas till hantverk och slöjdande. Även om det i den danska studien förmedlas hågkomster av hur händers renhet inspekterades innan textilslöjdslektioner har intervjuerna inte enbart anknytning till slöjdundervisning. Det gemensamma i dessa minnen är upplevelsen av starka känslor. Detta leder mig vidare till att fråga: skapar just undervisning i slöjd dessa känslor eller är känslan något som generellt kan vara en konsekvens av undervisningssituationer? Ett svar kan vara att Tanggard och Nielsens studie visar att olika aspekter på disciplin och lärarnas förmåga eller oförmåga att implementera regler är frekvent förekommande i tidigare elevers minnen - inte bara från slöjdundervisning. Samtidigt kan hågkomster av upplevelser från slöjdlektioner påverkats av att produkten som en materialisering av den egna prestationen finns kvar, till detta kommer ett minne av den egna kampen och ofta en lärare som påpekade misslyckanden. 


\section{Implikationer och möjligheter}

Denna essä vilar på ett antagande om att inte alla skolämnen väcker minnen i samma utsträckning. Antagandet knyts till det faktum att slöjden innefattar en handlingsburen kunskap som ofta leder till materiella resultat - föremål - och att detta skiljer slöjdämnet från andra ämnen i grundskolan.

Kan minnen från slöjdundervisning bidra till att generera förståelse för vad som skapar hågkomster? I resonemanget ovan har jag lyft att föremåls betydelse påverkas av bland annat tid och kontext (Wettstein, 2009) samt att ting kan hjälpa oss att minnas men att minnet påverkas av den tid som passerat (Gunnemark, 2004). Till det kan adderas att Halbwachs (1992) i sin teori om kollektivt minne menar att minnen påverkas av den tid i vilken de konstrueras. Det som individer kommer ihåg är en del av ett kollektivt minne och detta är ett samspel mellan de ramar som både formar och framkallar minnet; ramarna är beroende och skapare av minnen. Här förs ett resonemang där empiri som består av hågkomster av föremål och slöjdundervisning knyts till litteratur. Grunden för resonemanget består av individuella minnen som brevskrivare själva valt att nedteckna. De valda hågkomsterna skapar tillsammans ett kollektivt minne av skolslöjd. Breven är inte representativa för hela det moderna slöjdämnet, exempelvis genom att de inte skildrar de båda materialinriktningarna, trä och metall samt textil, i lika hög grad. Trots de källkritiska reservationer som presenterats anser jag att empirin och den valda litteraturen bidrar till förståelse av vad elever minns samt ger en grund för reflektioner gällande föremålens roll i slöjdundervisning och undervisningens utformning. Samtliga brev beskriver minnen av slöjdundervisning och slöjdföremål. Tillverkningen av föremål är därmed central i samtliga brev, oavsett vilken tidsperiod eller materialinriktning som skildras.

Såväl föremål som den arbetsprocess som leder fram till föremålet finns tydligt representerade i de tidigare elevernas minnen. Beskrivningarna av dessa båda företeelser förmedlas i många fall i känslosamma ordalag; de positiva minnena finns men negativa beskrivningar dominerar. Här bör påpekas att uppropets formulering kan ha påverkat såväl brevens innehåll som de känslor som innehållet förmedlas med. Med hjälp av Deweys text (1938/1997), som behandlar att "mis-education" kan leda till oönskat lärande, kan en förståelse skapas angående de negativa minnen som förmedlas i breven. De tidigare elevernas upplevelser av misslyckanden som manifesteras i produkter kan ses som negativa upplevelser som i sin tur leder till ett oönskat lärande, som hämmat fortsatt lärande i slöjd. Det finns minnen som lett till att individer aldrig mer slöjdat, men det finns även de hågkomster som skapat revanschtankar och ett 
intensivt slöjdande som vuxen. Deweys resonemang tyder på att en upplevelse av att ha lärt sig något under problematiska former kan förstärka ett minne och därmed bidra till att de föremål som tillverkats i undervisningen har en stark position i individers minnesbilder. Elevens förväntningar och känslomässiga engagemang kan även bidra till vad eleven kommer ihåg. Även Halbwachs (1992) presenterar tankegångar om att exempelvis smärtsamma minnen från det förgångna ger starka minnesbilder. Det kan även vara så att upplevelser glöms bort efter en tid, exempelvis då människor i det förflutna inte längre påverkar eller utövar makt över oss. Det ramverk individer speglar minnet mot har då förändrats på grund av den tid som förflutit sedan en upplevelse.

Kan vi lära något av de minnen som breven förmedlar? De styrdokument som reglerar undervisningen, synen på barn och lärarens roll i undervisningssituationer har förändrats över tid, vilket gör att vissa minnen som förmedlas inte alltid kan relateras till samtiden. De tidigare elevernas minnen kan därför inte anses fullt representativa för dagens undervisning, däremot kan de ses som exempel på vilka minnen som tycks stanna kvar hos eleven. Företrädare för slöjd kan utifrån vad de tidigare elever berättar fundera över vad som kan bilda bestående minnen hos dagens elever.

Slöjdandet, det erfarenhetsbaserade lärandet, och föremålen är centrala i de brev som här analyserats. Detta leder till frågor om individer minns slöjdföremålen för dess egen skull, om de minns föremålen för att de själva tillverkat dem eller om individer istället minns vad som lärts genom slöjdföremålen? Det tycks som om minnet av den kamp, ansträngning eller glädje som fanns vid tillverkningstillfället påverkar minnet eller upplevelsen av föremålet. Lärandet är också färgat av den känsla som upplevts och som beskrivits i breven, vilket lett till att ett livslångt minne uppstått. Breven visar att elever som kommer ihåg slöjden med glädje i högre grad tycks fortsätta använda det som lärts i slöjden. Minnena är starka och levande, de tidigare eleverna verkar komma ihåg den undervisning som skedde för många decennier sedan. De minnen som innehåller vissa motgångar och ansträngningar, men också ett färdigt föremål är något som skulle kunna verka som ett incitament för en anpassning av undervisningen till elevens förmåga. Lärarens roll kan inte underskattas, då läraren som en god ledare, pedagog och vuxenförbild tar en stor plats i tidigare elevers minnen av slöjdande. Samtidigt skrivs i breven från 1980-talet och framåt i något högre grad än tidigare att eleven "lärde av misstag - glömmer aldrig" eller att de i undervisningen "såg ett tydligt resultat". En elev som hade slöjd under 1980talet skriver "Jag älskade alla moment i träslöjden, hur tålamodskrävande det än var. Eller kanske just därför." Kanske är det så att breven även visar på att en 
förändring skett i slöjdundervisningen och att lärande över tid kommit att innefatta föremålen och tillverkningen av dessa men även en högre grad av reflektion, och att detta kan utgöra ett stöd för elever att minns det erfarenhetsbaserade lärandet genom föremålen.

\section{Referenser}

Ascenzi, A, \& Patrizi, E. (2016). Inside School Lives: Historiographical Perspectives and Case Studies. Teachers' Memories Preserved at the Centre for Documentation and Research on the History of Schoolbooks and Children's Literature. Espacio, Tiempo y Educación, 3(1), 343-362. https://doi.org/10.14516/ete.2016.003.001.16

Bergström, G. \& Boréus, K. (2000). Textens mening och makt: metodbok i samhällsvetenskaplig textanalys. Lund: Studentlitteratur.

Borg, K. (2001). Slöjdämnet: intryck - uttryck - avtryck. Diss: Linköping universitet. https://doi.org/10.3384/diss.diva-143165

Dewey, J. (1938/1997). Experience and education. ([New ed.]). New York: Simon \& Schuster.

Glassie, H. (1999). Material culture. Bloomington, Ind.: Indiana Univ. Press.

Gunnemark, K. (2004). Minnenas galleri: om minnesskåp och kulturarv. Stockholm: Carlsson.

Halbwachs, M. (1992). On collective memory. Chicago: University of Chicago Press. https://doi.org/10.7208/chicago/9780226774497.001.0001

Marjanen, P., Lindfors, E., \& Ketola, S. (2018). School Craft in Memories of Three Generations. Techne serien - Forskning i Slöjdpedagogik och Slöjdvetenskap, 25(1), 116. Hämtad från https://journals.hioa.no/index.php/techneA/article/view/2163

Meda, J. \& Viño, A. (2017). School Memory: Historiographical Balance and Heuristics perspectives. Ingår i: Yanes-Cabrera, C., Meda, J. \& Viñao, A. (red.), School memories: new trends in the history of education. Cham: Springer International Publishing. https://doi.org/10.1007/978-3-319-44063-7_1

Miller, D. (red.) (1998). Material cultures: why some things matter. Chicago: University of Chicago Press. https://doi.org/10.4324/9780203167014

Rasmussen, L. R. (2012). Touching Materiality: Presenting the past of everyday school life. Memory Studies, 5(2), 114-130. https://doi.org/10.1177/1750698011412147

Sennett, R. (2008). The craftsman. New Haven: Yale University Press.

Tanggard, L. \& Nielsen, K. (2013). School Memories Situating School. Scandinavian Journal of Educational Research, 57(1), 71-88. https://doi.org/10.1080/00313831.2011.621974

Westerlund, S. (2015). Lust och olust: elevers erfarenheter i textilslöjd. Diss: Umeå universitet.

Wettstein, M. (2009). Liv genom tingen: människor, föremål och extrema situationer. Eslöv: Brutus Östlings bokförlag Symposion.

Widén, P. (2009). Kvalitativ textanalys. Ingår i: A. Fejes \& R. Thornberg. (red.), Handbok i kvalitativ analys. (1. uppl.) Stockholm: Liber. 
Arkivmaterial

SKOLSLÖJD/2011, D488. Nordiska museets arkiv, Stockholm

\section{Bildkällor}

Bild 1: Fotograf: Elisabeth Eriksson @ () Nordiska museet

Bild 2: Fotograf: Peter Segemark (C) Nordiska museet

Bild 3: Fotograf: Thomas Adolfsson (C) Nordiska museet

Bild 4: Fotograf: Thomas Adolfsson ( Nordiska museet

Annelie Holmberg, Universitetslektor i textilvetenskap, Uppsala universitet. Holmbergs forskningsintresse har sin grund i personlig praktiskkunskap i textilt hantverk, yrkesverksamhet inom en tradition av mästarlära och slöjdlärarutbildning. Erfarenheterna har påverkat forskningsinriktningen och denna har kommit att innefatta forskning inom så väl slöjdfältet som textilvetenskaplig forskning om textila hantverkstraditioner. I båda dessa inriktningarna finns ett intresse för förändring från dåtid till nutid, förändringar som studerats i såväl föremål, skriftliga dokument som muntliga källor. I forskningen finns en övergripande strävan om att visa på hur förändring sker (eller inte sker) i såväl skolans slöjd som lärande av ett hantverk. 
Slöjdkunnande i förändring - Eleverna och slöjden

Techne Series A: 28(4), 2021 133-148 